\title{
RELEASE OF BIOACTIVE SUBSTANCES FROM FORMULATIONS CONTAINING ARTHROSPIRA PLATENSIS (SPIRULINA PLATENSIS)
}

\author{
BOŻENA MUSZYŃSKA ${ }^{1 *}$, JAN LAZUR $^{1}$, AGATA KRAKOWSKA $^{2}$, BARBARA JEKOT $^{1}$, \\ AGNIESZKA SZEWCZYK ${ }^{1}$, KATARZYNA SUŁKOWSKA-ZIAJA ${ }^{1}$, ŁUKASZ ZIMMER $^{3}$, \\ EWA POLESZAK ${ }^{3}$ and WŁODZIMIERZ OPOKA ${ }^{2}$
}

${ }^{1}$ Department of Pharmaceutical Botany, ${ }^{2}$ Department of Inorganic and Analytical Chemistry, Faculty of Pharmacy, Jagiellonian University Medical College, Medyczna 9, 30-688 Kraków, Poland ${ }^{3}$ Chair and Department of Applied Pharmacy, Medical University of Lublin,

Chodźki 1, Lublin 20-093, Poland

\begin{abstract}
Arthrospira platensis (Spirulina platensis) is a well-known microalga and has been utilized as a medicinal agent and foodstuff by humans since at least $16^{\text {th }}$ century. The aim of this study was to determine zinc content as well as determine phenolic and indole compounds from commercial preparations containing Arthrospira platensis (lyophilizate, tablets, and capsules) before and after extraction with methanol and incubation with artificial digestive juices. The secondary aim of this study was to evaluate the quality of these preparations. The samples were incubated in artificial stomach juice and in intestinal juice. The samples were mineralized and their zinc(II) ions content was estimated using flame absorption atomic spectroscopy (F-AAS). The maximum zinc(II) ions content released into the digestive juices was found to be up to $1.6 \mathrm{mg} / 100 \mathrm{~g}$ of the preparation. Phenolic compounds identified in the examined extracts are as follows: gallic acid; protocatechuic acid; 3,4-dihydroxyphenylacetic acid; p-hydroxybenzoic acid; syringic acid; cinnamic acid; and quercetin. Furthermore, indole compounds identified were 5-hydroxy-L-tryptophan, 5-methyl-L-tryptophan, L-tryptophan, tryptamine, and 5-methyltryptamine. Consequently, it was also found that the distributed Arthrospira platensis in the form of tablets does not disintegrate in the artificial digestive juices. Among the examined preparations, only hard capsules met the requirements of the European Pharmacopeia $8^{\text {th }}$ ed.
\end{abstract}

Keywords: Arthrospira platensis, artificial digestive juices, indole compounds, phenolic compounds, zinc

Arthrospira platensis (Spirulina platensis) has been used as a food by the Aztecs since the $16^{\text {th }}$ century in Mexico when it was fished from Lake Texaco and then dried and sold in the form of biscuits as described by Spanish soldiers. A. platensis is currently cultivated and is used in many countries as a dietary supplement because of its substantial nutritional value (1-3). Arthrospira maxima and Arthrospira platensis are the species classified as Spirulina, and most commonly these species are used in dietary supplements. The protein content in $A$. platensis is approximately $65-79 \%$ and is a complete source of protein and amino acids. About $7 \%$ of the weight of A. platensis contains lipids, mainly comprising $\gamma$-linolenic acid, $\alpha$-linolenic acid, stearic acid, eicosapentaenoic acid, docosahexaenoic acid, and arachidonic acid. A. platensis also contains significant amounts of $\gamma$-linolenic acid $(4,5)$. A platensis is a good source of water-soluble vitamins such as $\mathrm{C}$, $\mathrm{PP}$ (niacin) from group $\mathrm{B}\left(\mathrm{B}_{1}, \mathrm{~B}_{2}, \mathrm{~B}_{5}, \mathrm{~B}_{6}\right.$, and $\mathrm{B}_{12}$ ); fat-soluble vitamins, such as $\mathrm{A}, \mathrm{D}, \mathrm{E}$, and $\mathrm{K}$; and eicosapentaenoic acid. It is also a good source of macro and microelements, such as $\mathrm{P}, \mathrm{Ca}, \mathrm{K}, \mathrm{Na}, \mathrm{Mg}$, $\mathrm{Fe}$ and also contains inositol and dyes (phycocyanins, carotenoids, and chlorophyll b) $(6,7,8)$. Phycocyanin, belonging to the water-soluble pigments phycobilins ( $1 \%$ of A. platensis mass), is mainly responsible for its ability to neutralize free radicals. This blue dye gives $A$. platensis its characteristic, dark-turquoise color. It also contains carotenoids such as $\beta$-carotene and $\beta$-cryptoxanthin as well as chlorophyll a and b. A. platensis is used in the prevention and treatment of various diseases such as obesity, anemia, hypertension, hyperlipidemia, diabetes, some cancers, neurodegenerative diseases such as Alzheimer's disease, and so on (9-13). Due to the antioxidant, anti-inflammatory, antidepressant, and immunostimulatory properties

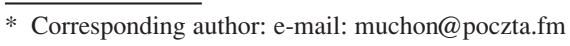


of A. platensis described earlier in the scientific literature, it was decided to determine its content of zinc, phenolic, and indole compounds (14-16).

Zinc is essential for the proper development of human body. This element is not only an activator but is also a cofactor of about 300 enzymes. Zinc is responsible for the metabolism of nucleic acids, proteins, lipids, and carbohydrates (17). It affects the expression of genes during the replication and transcription of DNA and RNA (17). It is also responsible for the synthesis of red blood cells and affects the functions of inter alia respiratory, reproductive, and immune systems $(18,19)$ and also demonstrates an anti-inflammatory, regenerating and antidepressant activity.

Phenolic and indole compounds primarily exhibit an antioxidant, anti-inflammatory, and immunostimulant activity.

The aim of this study was to perform quantitative analysis of zinc ions as well as phenolic and indole compounds in preparations of commercial origin containing A. platensis before and after an extraction using artificial digestive juices. Flame absorption atomic spectroscopy (F-AAS) was used to analyze zinc, whereas phenolic and indole compounds were determined using reverse phase-high performance liquid chromatography (RP-HPLC).

The analysis was performed to evaluate the highest amounts of bioelements, phenolic, and indole compounds and zinc (II) ions released among the preparations containing A. platensis (lyophilizate, tablets, and capsules) after the extraction using artificial digestive juices. The final product will be a better source of these substances for human consumption. In addition, the next aim of the work was to evaluate whether the formulation containing A. platensis is suitable for the effective release of zinc and phenolic and indole compounds and whether it meets the pharmacopeia requirements.

\section{EXPERIMENTAL}

\section{Reagents and standards}

Standard zinc (II) ions solution at a concentration of 1000 ppm was obtained from OUM (Łódź, Poland); subsequent dilutions of 100, 10, and 1 ppm concentrations were prepared from the above solution. $\mathrm{MgCl}_{2}$ was obtained from Chempur (Kraków, Poland); $\mathrm{NaCl}, \mathrm{KCl}$, and $\mathrm{NaHCO}_{3}$ were obtained from PPH Golpharm (Kraków, Poland); pepsin and bile salts were obtained from BTL (Łódź, Poland); $\mathrm{CaCl}_{2}$ was obtained from Pharma Zentrale $\mathrm{GmbH}$ (Germany); pancreatic extract, $\mathrm{HCl}, \mathrm{KCl}$, concentrated $\mathrm{HNO}_{3}$ Suprapur ${ }^{\circledR}$, and $\mathrm{KNO}_{3}$, Suprapur ${ }^{\circledR}$ were obtained from Merck (Darmstadt, Germany); $\mathrm{C}_{6} \mathrm{H}_{8} \mathrm{O}_{7}, \mathrm{ZnSO}_{4}, \mathrm{KHCO}_{3}, \mathrm{Na}_{2} \mathrm{HPO}_{4}, \mathrm{~K}_{2} \mathrm{HPO}_{4}$, and $\mathrm{NaOH}$ were purchased from Polish Company of Chemistry (Gliwice, Poland). Water (quadruple-distilled) with the conductivity of less than $1 \mu \mathrm{S} / \mathrm{cm}$ was obtained using an S2-97A2 distillation apparatus (ChemLand, Stargard Szczecin, Poland). The following standard phenolic compounds of HPLC grade were purchased from Fluka Chemie Gmbh (Switzerland): $p$-coumaric acid; ferulic acid; $p$ hydroxybenzoic acid; vanillic acid; and 3,4-dihydrophenylacetate acid. Caffeic acid, chlorogenic acid, cinnamic acid, $o$-coumaric acid, protocatechuic acid, sinapic acid, gallic acid, and syringic acid and quercetin and standards of indole compounds, namely, L-tryptophan, 5-hydroxy-L-tryptophan, 6-methyl-L-tryptophan, serotonin, melatonin, tryptamine, and 5-methyl-tryptamine were purchased from Sigma-Aldrich (St. Louis, MO, USA); all were of HPLC grade. Methanol, acetic acid, and petroleum ether were purchased from Merck (Darmstadt, Germany) were also of HPLC grade.

\section{Research material}

The studies were conducted on the dietary supplements containing Arthrospira platensis (microalgae from Microcoleaceae family), two preparations in the powdered form and two in the tablet form, and one in capsules were evaluated. Both, the methanolic extracts of these preparations and the extracts obtained after incubation with artificial digestive juices were objects of the experiment. The selected preparations differed in preparation form and dosage and were derived from different manufacturers (Table 1).

\section{Preparation of artificial digestive juices}

Artificial saliva $(\mathrm{pH}=6.8$. $)$ was prepared according to the method of Arvidson (20). Briefly,

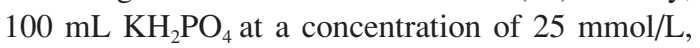
$100 \mathrm{~mL} \mathrm{Na} \mathrm{HPO}_{4}$ at a concentration of $24 \mathrm{mmol} / \mathrm{L}$, $100 \mathrm{~mL} \mathrm{KHCO}_{3}$ at a concentration of $150 \mathrm{mmol} / \mathrm{L}$, $100 \mathrm{~mL} \mathrm{MgCl}_{2}$ at a concentration of $1.5 \mathrm{mmol} / \mathrm{L}$, $6 \mathrm{~mL}$ citric acid at a concentration of $25 \mathrm{mmol} / \mathrm{L}$, $100 \mathrm{~mL} \mathrm{CaCl}{ }_{2}$ at a concentration of $15 \mathrm{mmol} / \mathrm{L}$ were added to the flask and the volume was made up to $1000 \mathrm{~mL}$ with four-times distilled water.

Artificial stomach juice $(\mathrm{pH}=2.0)$ was prepared according to the method described in Polish Pharmacopeia X. Briefly, $2.0 \mathrm{~g} \mathrm{NaCl}$ and $3.2 \mathrm{~g}$ pepsin were dissolved in four-times distilled water. Then, $80 \mathrm{~mL} \mathrm{HCl}$ at a concentration of $1 \mathrm{~mol} / \mathrm{L}$ was added, and the volume was made up to $1 \mathrm{~L}$ using four-times distilled water (21). 
Artificial intestinal juice $(\mathrm{pH}=8.0)$ was prepared according to the method of Neumann (22). Briefly, $20 \mathrm{mg}$ pancreatic extract, $120 \mathrm{mg}$ bile salt, and $8.4 \mathrm{~g} \mathrm{NaHCO}_{3}$ were dissolved in four-times distilled water and the volume was made up to $1 \mathrm{~L}$ using four-times distilled water.

\section{Sample preparation}

Release studies were performed in the Gastroel-2014 apparatus, which was constructed at the Department of Inorganic and Analytical Chemistry at the Faculty of Pharmacy, Medical College, Jagiellonian University. This apparatus allows the study of substances released into the artificial digestive juices, imitates gastrointestinal motions, and also provides a constant temperature of $37^{\circ} \mathrm{C}$ (23).

Preparations containing A. platensis were weighed (at $0.5 \mathrm{~g}$ ) and after performing mineralization three parts of the samples were made: one part of the samples was used to determine zinc (II) ions content, the second for methanol extraction (phenolic and indole compounds) while the other part was subjected to in vitro digestion using Gastroel-2014. The second part was used for three times extraction by $100 \mathrm{~mL}$ of methanol using ultrasound at a frequency of $49 \mathrm{kHz}$ during 30 minutes (Sonic-2, Polsonic, Poland). For the last part, the weighed sample was transferred to $100 \mathrm{~mL}$ Erlenmeyer flasks and then wetted with $2 \mathrm{~mL}$ of artificial saliva; subsequently, $100 \mathrm{~mL}$ of stomach juice was added. The flasks were closed with a stopper and placed in the apparatus. The incubation process was continued for 15, 30, and $60 \mathrm{~min}$. The resulting solutions were filtered using a Büchner funnel and a vacuum set. The residue was transferred to Erlenmeyer flasks together with the filter paper and $100 \mathrm{~mL}$ of intestinal juice was added (the extraction process lasted $150 \mathrm{~min}$ ). Then, the contents were filtered again. The samples were divided into two lots, one of which was designated for zinc analysis and the other for the analysis of organic compounds (phenolic and indole compounds).
Analysis of $\mathrm{Zn}$ content before and after incubation with artificial digestive juices using the FAAS method

The concentration of zinc (II) was determined using the F-AAS method. Mineralization of the preparations containing A. platensis was performed in the Magnum II microwave mineralizer ERTEC (Poland). Mineralization was performed for $1 \mathrm{~h}$ in three magnetron cycles: $15 \mathrm{~min}$ at $60 \%$ power, 15 $\min$ at $80 \%$ power, and $30 \mathrm{~min}$ at $100 \%$ power. Mineralization of solutions after incubation with artificial digestive juices using Gastroel-2014 was performed in the UV R-8 Mineral Poland mineralizer. This process was performed by UV irradiation of the mineralized test solution in a quartz reaction vessel in 5 cycles of $6-8 \mathrm{~h}$.

Thermo Scientific AA Spectrometer iCE 3000 SERIES (USA) was used in all the measurements of zinc.

Reverse-phase high performance liquid chromatography (RP-HPLC) of phenolic compounds

The extracts obtained from methanol and after incubation with artificial digestive juices were analyzed for phenolic compounds using the method of RP-HPLC, which was performed based on the procedure developed by Sułkowska-Ziaja (24). The analysis was performed at $25^{\circ} \mathrm{C}$, with a mobile phase consisting of $\mathrm{A}-$ methanol and $\mathrm{B}$ - methanol: $0.5 \%$ acetic acid $1: 4(\mathrm{v} / \mathrm{v})$. The following gradient was applied: $100 \%$ B for 0-20 min; $100-80 \%$ B for 20-35 min; $80-60 \%$ B for 35-55 min; $60-0 \%$ B for 55-70 min; 0\% B for 70-75 min; 0-100\% B for 75-80 $\mathrm{min} ; 100 \% \mathrm{~B}$ for $80-90 \mathrm{~min}$ at a flow rate 1 $\mathrm{mL} / \mathrm{min}, \lambda=254 \mathrm{~nm}$ (phenolic acids), $\lambda=370 \mathrm{~nm}$ (flavonoids). Quantification was performed by the measurement of peak area with reference to the standard curve derived from five concentrations $(0.03125-0.5 \mathrm{mg} / \mathrm{mL})$. The quantitative analysis of phenolic compounds was performed using a calibration curve with the assumption of the linear size of the area under the peak and the concentration of the

Table 1. Dietary supplements containing Arthrospira platensis which were used for determination of zinc content after an extraction to artificial digestive juices.

\begin{tabular}{|c|c|c|}
\hline Name of the preparation & Form & Expiry date \\
\hline Spirulina B & Powder & 11.2016 \\
\hline Spirulina P & Powder & 07.2012 \\
\hline Spirulina M & Capsules & 10.2016 \\
\hline Spirulina N & Tablets & 08.2016 \\
\hline Spirulina O & Tablets & 03.2017 \\
\hline
\end{tabular}


reference standard. The results were expressed in $\mathrm{mg} / 100 \mathrm{~g}$ of dry weight (d.w.).

\section{RP-HPLC analysis of indole compounds}

The extracts obtained from methanol and after incubation with digestive juices were evaporated to dryness under pressure of $200 \mathrm{mBa}$ at $40^{\circ} \mathrm{C}$ (Büchi evaporator, Germany). The concentrated analyte was dissolved in methanol transferred through Whatman No. 3 filter paper. The extracts were quantitatively dissolved in $1.5 \mathrm{~mL}$ of solvent system (methanol : water : ammonium acetate at 15:14:1 $\mathrm{v} / \mathrm{v} / \mathrm{v}$ ) and subjected to separation by RP-HPLC using the Hitachi HPLC (Merck, Japan) equipped with a pump type L-7100, the Purospher ${ }^{\circledR}$ RP-18 (4 $\times 200 \mathrm{~mm}, 5 \mu \mathrm{m})$ column kept at $25^{\circ} \mathrm{C}$ and UV detector operated at $\lambda=280 \mathrm{~nm}$. The isocratic separation was as follows: methanol/water/ammonium acetate $(15: 14: 1 \mathrm{v} / \mathrm{v} / \mathrm{v})$ at a flow rate of $1 \mathrm{~mL} / \mathrm{min}$. The quantitative analysis of indole compounds was performed using a calibration curve with the assumption of the linear size of the area under the peak and the concentration of the reference standard. Quantification was performed by the measurement of peak area with reference to the standard curve derived from five concentrations $(0.0625-1$ $\mathrm{mg} / \mathrm{mL}$ ). The results were expressed in $\mathrm{mg} / 100 \mathrm{~g}$ of d.w.

\section{Properties of tablets}

The tablets were evaluated as per standard procedure according to European Pharmacopeia $8^{\text {th }}$ ed for uniformity of weight, hardness, friability, and disintegration time (25). Tablets were also tested for variation in thickness to determine any variability associated with the tablet press or the method of preparation.

The average weight was obtained according to pharmacopeia limits by weighing randomly selected 20 tablets on an analytical balance (OHAUS Adventurer Pro). The hardness of the tablets was determined for at least 10 tablets using the Erweka TBH 20 hardness tester (Erweka GmbH), and adopting a minimum hardness of $40 \mathrm{~N}$ as the acceptance criterion. For each formula, friability was evaluated from the percentage weight loss of 20 tablets tumbled in Erweka TAR 120 friabilator (Erweka $\mathrm{GmbH}$, Hausenstamm, Germany) at $25 \mathrm{rpm}$ for $4 \mathrm{~min}$. The tablets were dedusted and the loss in weight caused by fracture or abrasion was recorded as the percentage weight loss. Friability $<1 \%$ was considered acceptable. Respective disintegration times of the prepared tablets were measured in 900 $\mathrm{mL}$ of purified water with disks at $37^{\circ} \mathrm{C}$ using an Erweka ZT 222 tester (Erweka GmbH, Hausenstamm, Germany). Six tablets were randomly selected from each formulation and were put into basketrack. The disintegration time was recorded till all the fragments of the disintegrated tablet passed through the screen of the basket. For non-modified tablets, the disintegration time should not be longer than 15 min. The thickness of the tablets was determined for 20 tablets using digimatic Vernier caliper (0-150 $\mathrm{mm})$.

\section{Statistical analysis}

Statistical analysis of the data was performed using one-way ANOVA with Tukey-Kramer post hoc analysis of multiple comparisons. A value $\mathrm{p}<$ 0.05 was accepted as the level of statistical significance.

\section{RESULTS AND DISCUSSION}

This is the first study where the content of zinc, phenolic and indole compounds in commercial preparations of A. platensis from different manufacturers were analyzed. Furthermore, the level of these compounds release was investigated using Gastroel2014 apparatus which imitates conditions in the human digestive tract. Selected commercially available preparations as dietary supplements differed in

Table 2. Zinc content in selected preparations containing Arthrospira platensis.

\begin{tabular}{|c|c|}
\hline Preparation & $\begin{array}{c}\text { Zinc content in preparations containing spirulina } \\
(\mathrm{mg} / 100 \mathrm{~g} \pm \mathrm{SD})\end{array}$ \\
\hline Spirulina B & $1.87 \pm 0.05$ \\
\hline Spirulina P & $0.38 \pm 0.02$ \\
\hline Spirulina M & $0.63 \pm 0.03$ \\
\hline Spirulina N & $1.17 \pm 0.06$ \\
\hline Spirulina O & $1.15 \pm 0.07$ \\
\hline
\end{tabular}

The data presented was mean \pm SD (standard deviation); $\mathrm{n}=6$ 
Table 3. The content of zinc released to artificial digestive juices from selected Arthrospira platensis - containing preparations.

\begin{tabular}{|c|c|c|c|c|c|c|}
\hline \multirow{2}{*}{$\begin{array}{c}\begin{array}{c}\text { Digestive } \\
\text { juice }\end{array} \\
\begin{array}{c}\text { Time } \\
\text { [min] }\end{array}\end{array}$} & \multicolumn{3}{|c|}{ Stomach juice } & \multicolumn{3}{|c|}{ Intestinal juice (150 min) } \\
\hline & 15 & 30 & 60 & $\begin{array}{c}\text { after } 15 \text { in } \\
\text { stomach juice }\end{array}$ & $\begin{array}{c}\text { after } 30 \text { in } \\
\text { stomach juice }\end{array}$ & $\begin{array}{c}\text { after } 60 \text { in } \\
\text { stomach juice }\end{array}$ \\
\hline \multicolumn{7}{|c|}{ Amount of $\mathrm{Zn}$ released (mg $100 \mathrm{~g}^{-1}$ of preparation) } \\
\hline \multicolumn{7}{|c|}{ Spirulina B (powder) } \\
\hline & $0.60 \pm 0.04^{\mathrm{a}}$ & $1.56 \pm 0.50^{\mathrm{a}}$ & $0.33 \pm 0.02^{\mathrm{a}}$ & $0.14 \pm 0.05^{\mathrm{a}}$ & $0.14 \pm 0.05^{\mathrm{a}}$ & $0.39 \pm 0.03^{\mathrm{a}}$ \\
\hline \multicolumn{7}{|c|}{ Spirulina $\mathrm{P}$ (powder) } \\
\hline & $0.91 \pm 0.07^{\mathrm{a}, \mathrm{b}, \mathrm{c}}$ & $1.14 \pm 0.04^{\mathrm{a}, \mathrm{b}, \mathrm{c}, \mathrm{d}}$ & $0.67 \pm 0.04^{\mathrm{a}, \mathrm{b}, \mathrm{c}, \mathrm{d}}$ & $0.16 \pm 0.01^{\mathrm{b}, \mathrm{d}}$ & $0.20 \pm 0.00^{\mathrm{a}, \mathrm{c}, \mathrm{d}}$ & $1.05 \pm 0.01^{\mathrm{a}, \mathrm{b}, \mathrm{c}, \mathrm{d}}$ \\
\hline \multicolumn{7}{|c|}{ Spirulina M (capsules) } \\
\hline & $0.50 \pm 0.17^{\mathrm{b}}$ & $0.62 \pm 0.04^{\mathrm{a}, \mathrm{b}}$ & $0.35 \pm 0.06^{\mathrm{a}, \mathrm{b}}$ & $0.24 \pm 0.0^{\mathrm{a}, \mathrm{b}}$ & $0.16 \pm 0.02^{\mathrm{b}}$ & $0.12 \pm 0.00^{\mathrm{a}, \mathrm{b}}$ \\
\hline \multicolumn{7}{|c|}{ Spirulina N (tablets) } \\
\hline & $0.26 \pm 0.03^{\mathrm{a}, \mathrm{b}, \mathrm{c}}$ & $0.27 \pm 0.02^{\mathrm{a}, \mathrm{c}}$ & $0.403 \pm 0.08^{\mathrm{b}, \mathrm{c}}$ & $0.13 \pm 0.00^{\mathrm{b}, \mathrm{c}}$ & $0.15 \pm 0.02^{\mathrm{c}}$ & $0.15 \pm 0.00^{\mathrm{a}, \mathrm{b}, \mathrm{c}}$ \\
\hline \multicolumn{7}{|c|}{ Spirulina O (tablets) } \\
\hline & $0.21 \pm 0.02^{\mathrm{a}, \mathrm{b}, \mathrm{d}}$ & $0.40 \pm 0.08^{\mathrm{ce}, \mathrm{d}}$ & $0.22 \pm 0.02^{\mathrm{a}, \mathrm{b}, \mathrm{c}, \mathrm{d}}$ & $0.27 \pm 0.04^{\mathrm{a}, \mathrm{c}, \mathrm{d}}$ & $0.05 \pm 0.01^{\mathrm{a}, \mathrm{b}, \mathrm{c}, \mathrm{d}}$ & $0.09 \pm 0.02^{\mathrm{a}, \mathrm{b}, \mathrm{c}, \mathrm{d}}$ \\
\hline
\end{tabular}

Data are presented as the mean \pm standard deviation $(\mathrm{SD}) ; \mathrm{n}=6$ repetitions Tukey-Kramer test was used to reveal the differences between paired groups of zinc in rows, the same letters (a, b, c, d, e) are marked for the content whose differences are statistically significant (for p values < 0.05) (GraphPad InStat)

Spirulina species, preparation form (powdered lyophilizates, capsules, and tablets), dosage, and were derived from different manufacturers.

F-AAS was used to evaluate the content of zinc (II) ions in A. platensis-containing preparations that were incubated with artificial digestive juices. The elaborated conditions of lyophilized material mineralization and the analytical method allowed to determine the zinc(II) ions concentration in preparations and extracts of incubated preparations.

Zinc content in the examined preparations was found to be in the range of $0.38-1.87 \mathrm{mg} / 100 \mathrm{~g}$ of preparation (Table 2). The highest content of zinc (II) ions was determined in the powder form of preparation (1.87 $\mathrm{mg} / 100 \mathrm{~g}$ of preparation). The amount of zinc (II) ions released for artificial digestive juice varies within a narrow range of values and it depends on the degree of powdering the raw material in preparations. The content of zinc (II) ions in the dry matter of A. platensis according to previous studies has been reported as $2 \mathrm{mg} / 100 \mathrm{~g}$ (26). But, in this study, was found a considerably lower content of zinc (II) ions, $0.38 \mathrm{mg} / 100 \mathrm{~g}$ of preparation, in the powdered A. platensis (cell lyophilizate). For tablets, very similar amounts were determined, that is, in the range of $1.15-1.17 \mathrm{mg} / 100 \mathrm{~g}$ of preparation.

Al-Dhabi (2013) determined zinc (II) ions in A. platensis-containing preparations and obtained the results at a similar level $(0.05-0.6 \mathrm{mg} / 100 \mathrm{~g}$ of preparation) (27).
In order to estimate the actual quantities of this element available to the human body, incubation of preparations containing A. platensis with artificial digestive juices (in Gastroel-2014 apparatus) was performed under conditions imitating those in the human body (temperature $37^{\circ} \mathrm{C}$ and movements mimicking peristalsis of the human digestive tract). On the basis of F-AAS analysis was found that zinc (II) ions are better released from lyophilized $A$. platensis than that from tablets or capsules. The amount of zinc (II) ions released into the artificial digestive juices ranged from 0.05 to $1.56 \mathrm{mg} / 100 \mathrm{~g}$ of the preparation (Figs. 1a, b). The highest amount of zinc (II) determined in artificial stomach juice was in the range of 0.2 to $1.6 \mathrm{mg} / 100 \mathrm{~g}$ of the preparation, after $30 \mathrm{~min}$ of incubation (Table 3 ). In addition, these amounts in artificial intestinal juice were significantly lower, regardless of the incubation time in the stomach juice, which ranged from 0.1 to $0.4 \mathrm{mg} / 100 \mathrm{~g}$ of the preparation. The highest amounts were determined for Spirulina B, that is, preparation in the form of a cell lyophilizate (powder), and $1.6 \mathrm{mg} / 100 \mathrm{~g}$ of preparation was released into the stomach juice after $30 \mathrm{~min}$ of incubation (Figs. 1a, b). This preparation proved to be the most optimal due to the amount of zinc (II) ions found in both types of artificial digestive juices (stomach and intestinal) and in any time variant. Zinc (II) ions were more efficiently released from capsules than that from tablets, despite the demonstrated lower 
content of this element in the product before incubation with the artificial digestive juices. The degree of zinc (II) ions released into the artificial stomach juice was found to be lowest in stomach juice (in case of $15 \mathrm{~min}$ incubation). The daily human demand for this element is about $12 \mathrm{mg}$, that is, the amount released from the preparation can constitute zinc supplement to the human diet (28).

Phenolic and indole compounds were determined using RP-HPLC and the results of the calculations were converted to the amount of compounds released from $100 \mathrm{~g}$ of the preparation.

Commercial preparations of A. platensis are a good source of phenolic and indole compounds. In this study, we identified seven phenolic compounds (gallic acid; protocatechuic acid; 3,4-dihydroxyphenylacetic acid; $p$-hydroxybenzoic acid; syringic acid; cinnamic acid; and quercetin) in almost all commercial preparations (Table 4). Furthermore, 3,4-dihydroxy-phenylacetic acid and gallic acid were found to be highest among the examined phenolic compounds. It was best extracted from the powder form of preparation released in the artificial stomach juice, which was up to $38.1 \mathrm{mg} / 100 \mathrm{~g}$ of preparation. In addition, gallic acid was found to be released highest in the intestinal juice from capsules (Spirulina M) containing lyophilized A.platensis, up to a maximum of $7.3 \mathrm{mg} / 100 \mathrm{~g}$ of preparation. Other phenolic compounds were determined in both stomach and intestinal juices at a similar level of 0.01 to
$2.2 \mathrm{mg} / 100 \mathrm{~g}$ of preparation. It is estimated that 0.1 to $1.0 \mathrm{~g}$ daily dose of phenolic compounds is required in the human diet. This range is broad and depends largely on the diet, including the amount of consumed fruits, vegetables, coffee, or tea $(29,30)$. All the analyzed preparations were found to be a source of phenolic compounds. After conversion of the recommended daily dosage by manufacturers for the product, the total amount of phenolic compounds was determined, and on this basis, was demonstrated that the preparations may be a source of phenolic compounds up to $60.7 \mathrm{mg}$ /day for Spirulina P (lyophilizate).

The indole compounds determined in the preparations include 5-hydroxy-L-tryptophan, tryptamine, 5-methyltryptamine, 6-methyl-tryptophan, and L-tryptophan. They were determined in a significantly lower number of experimental variants than phenolic compounds. Compared to methanolic extracts, indole compounds were determined at higher concentrations in artificial digestive juices (Table 5). In addition, 5-hydroxy-L-tryptophan was indole compound found in the highest amounts in the digestive juices, up to $156.2 \mathrm{mg} / 100 \mathrm{~g}$ of preparation. Due to their numerous health benefits (antioxidant, anti-inflammatory, antidepressive etc.), indole compounds should be supplemented. The daily doses of indole compounds supplied from A. platensis - containing preparations (converted to the doses recommended by manufacturers) were the
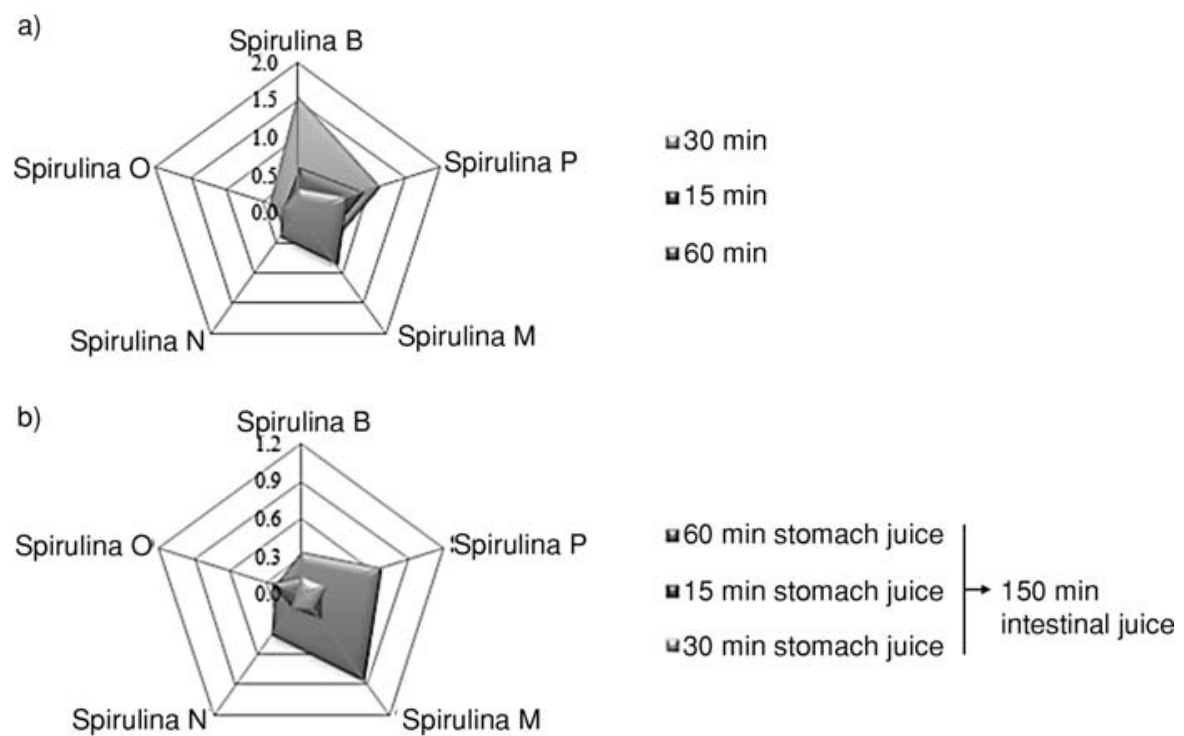

Figure 1. a) Total zinc content (mg/100 g of preparation) after extraction to stomach juice over the time of 15,30 , and $60 \mathrm{~min}$. b) Total zinc content ( $\mathrm{mg} / 100 \mathrm{~g}$ of preparation) after extraction to intestinal juice over the time of 15,30 , and 60 min incubation in stomach juice 
Table 4. The content of phenolic compounds released to artificial digestive juices from selected Arthrospira platensis-containing preparations.

\begin{tabular}{|c|c|c|c|c|c|c|c|}
\hline Artificial juice & \multicolumn{3}{|c|}{$\begin{array}{l}\text { Artificial stomach juice } \\
\text { (mg/100 g of preparation) }\end{array}$} & \multicolumn{3}{|c|}{$\begin{array}{l}\text { Artificial intestinal juice } \\
\text { (mg/100 } \mathrm{g} \text { of preparation) }\end{array}$} & \\
\hline \multirow{2}{*}{ Time $[\mathrm{min}]$} & 15 & 30 & 60 & 150 & 150 & 150 & \\
\hline & \multicolumn{3}{|c|}{ (after 1 min incubation in artificial saliva) } & \multicolumn{3}{|c|}{ (after incubation in artificial stomach juice) } & \\
\hline $\begin{array}{l}\text { Extract to artificial } \\
\text { digestive juice }\end{array}$ & & & & & & & $\begin{array}{c}\text { Methanolic } \\
\text { extract (control) }\end{array}$ \\
\hline \multicolumn{8}{|c|}{ Gallic acid } \\
\hline Spirulina B & $0.12 \pm 0.05^{\mathrm{a}}$ & $0.14 \pm 0.00^{\mathrm{a}}$ & $0.13 \pm 0.00^{\mathrm{a}}$ & $0.66 \pm 0.00^{\mathrm{a}}$ & $0.12 \pm 0.00^{\mathrm{a}}$ & $0.33 \pm 0.00^{\mathrm{a}}$ & $0.79 \pm 0.02^{a}$ \\
\hline Spirulina P & $0.18 \pm 0.00^{\mathrm{b}}$ & $0.38 \pm 0.00^{\mathrm{a}, \mathrm{b}}$ & $0.07 \pm 0.2^{\mathrm{a}, \mathrm{b}}$ & $2.13 \pm 0.33^{b}$ & $0.89 \pm 0.09^{b}$ & $1.38 \pm 0.00^{\mathrm{a}}$ & $0.67 \pm 0.04^{b}$ \\
\hline Spirulina M & $0.33 \pm 0.03^{\mathrm{a}, \mathrm{b}, \mathrm{c}}$ & $0.69 \pm 0.04^{\mathrm{a}, \mathrm{b}, \mathrm{c}}$ & $0.10 \pm 0.01^{\mathrm{a}, \mathrm{b}, \mathrm{c}}$ & $7.22 \pm 1.11^{\mathrm{a}, \mathrm{b}, \mathrm{c}}$ & $4.56 \pm 1.78^{\mathrm{a}, \mathrm{b}, \mathrm{c}}$ & $1.41 \pm 0.30^{\mathrm{a}, \mathrm{c}}$ & $2.44 \pm 0.17^{\mathrm{a}, \mathrm{b}, \mathrm{c}}$ \\
\hline Spirulina N & $0.01 \pm 0.00^{\mathrm{b}, \mathrm{c}, \mathrm{d}}$ & $0.02 \pm 0.03^{b, c, d}$ & $0.01 \pm 0.00$ & $0.62 \pm 0.58$ & $0.59 \pm 0.61$ & $0.42 \pm 0.40$ & $1.06 \pm 0.06$ \\
\hline Spirulina $\mathrm{O}$ & $0.10 \pm 0.00$ & $0.15 \pm 0.00$ & - & $7.31 \pm 0.81^{\mathrm{a}, \mathrm{b}, \mathrm{d}}$ & $2.32 \pm 0.38^{\mathrm{a}, \mathrm{c}}$ & $2.09 \pm 0.74^{\mathrm{a}, \mathrm{d}}$ & $0.81 \pm 0.02^{\mathrm{c}, \mathrm{d}}$ \\
\hline \multicolumn{8}{|c|}{ Protocatechuic acid } \\
\hline Spirulina B & $1.46 \pm 0.14^{\mathrm{a}}$ & $0.28 \pm 0.05^{\mathrm{a}}$ & $1.97 \pm 0.05^{\mathrm{a}}$ & $0.93 \pm 0.10^{\mathrm{a}}$ & $0.03 \pm 0.00^{\mathrm{a}}$ & $0.16 \pm 0.06^{\mathrm{a}}$ & $0.01 \pm 0.001^{\mathrm{a}}$ \\
\hline Spirulina $P$ & $1.44 \pm 0.14^{\mathrm{b}}$ & $0.01 \pm 0.00^{\mathrm{a}, \mathrm{b}}$ & $0.71 \pm 0.05^{\mathrm{a}, \mathrm{b}}$ & $0.01 \pm 0.00^{\mathrm{a}}$ & $0.30 \pm 0.02^{\mathrm{b}}$ & $0.50 \pm 0.05^{\mathrm{a}, \mathrm{b}}$ & $0.01 \pm 0.00^{\mathrm{b}}$ \\
\hline Spirulina M & $0.40 \pm 0.03^{\mathrm{a}, \mathrm{b}, \mathrm{c}}$ & $0.39 \pm 0.05^{\mathrm{b}, \mathrm{c}}$ & $2.22 \pm 0.60^{\mathrm{b}, \mathrm{c}}$ & $0.04 \pm 0.005$ & $0.01 \pm 0.001$ & $0.01 \pm 0.01$ & $0.01 \pm 0.01$ \\
\hline Spirulina N & $0.20 \pm 0.002^{\mathrm{a}, \mathrm{b}, \mathrm{d}}$ & $0.25 \pm 0.06^{\mathrm{b}, \mathrm{d}}$ & $0.64 \pm 0.04^{\mathrm{a}, \mathrm{c}}$ & $0.05 \pm 0.001^{\mathrm{a}}$ & $0.05 \pm 0.003^{b, c}$ & $0.01 \pm 0.00^{\mathrm{a}, \mathrm{b}}$ & $0.05 \pm 0.003^{c}$ \\
\hline Spirulina $\mathrm{O}$ & $1.25 \pm 0.27^{\mathrm{c}, \mathrm{d}}$ & $0.79 \pm 0.13^{\mathrm{a}, \mathrm{b}, \mathrm{c}, \mathrm{d}}$ & $0.93 \pm 0.0^{\mathrm{a}, \mathrm{c}}$ & $0.02 \pm 0.002^{\mathrm{a}}$ & $0.06 \pm 0.001^{\mathrm{a}, \mathrm{b}, \mathrm{c}}$ & $0.01 \pm 0.00^{\mathrm{a}, \mathrm{b}}$ & $0.01 \pm 0.002^{\mathrm{d}}$ \\
\hline \multicolumn{8}{|c|}{ 3,4-Dihydroxyphenylacetic acid } \\
\hline Spirulina B & $26.47 \pm 8.94^{\mathrm{a}}$ & $20.27 \pm 6.01^{\mathrm{a}}$ & $20.90 \pm 2.66^{\mathrm{a}}$ & $2.05 \pm 0.08^{\mathrm{a}}$ & $2.29 \pm 0.25$ & $4.49 \pm 0.20^{\mathrm{a}}$ & $1.13 \pm 0.11^{\mathrm{a}}$ \\
\hline Spirulina $\mathrm{P}$ & $38.14 \pm 2.25^{a, b}$ & $1.83 \pm 0.00^{\mathrm{a}}$ & $7.05 \pm 0.13^{\mathrm{a}, \mathrm{b}}$ & $2.27 \pm 0.19^{b}$ & $2.80 \pm 0.30^{b}$ & $9.48 \pm 2.11^{\mathrm{a}, \mathrm{b}}$ & $0.71 \pm 0.07^{\mathrm{b}}$ \\
\hline Spirulina M & $5.27 \pm 0.89^{a, b}$ & $6.55 \pm 1.27^{\mathrm{a}}$ & $25.15 \pm 2.12^{\mathrm{b}, \mathrm{c}}$ & $3.86 \pm 0.21^{\mathrm{a}, \mathrm{b}, \mathrm{c}}$ & $2.39 \pm 0.2$ & $1.95 \pm 0.04^{\mathrm{a}, \mathrm{b}}$ & $1.61 \pm 0.13^{c}$ \\
\hline Spirulina N & $2.05 \pm 0.00^{\mathrm{a}, \mathrm{b}}$ & $3.15 \pm 0.77^{a}$ & $7.96 \pm 0.24^{\mathrm{a}, \mathrm{c}}$ & $2.16 \pm 0.00^{\mathrm{c}, \mathrm{d}}$ & $2.00 \pm 0.16^{b}$ & $2.14 \pm 0.28^{a, b}$ & $5.77 \pm 0.38^{\mathrm{a}, \mathrm{c}, \mathrm{d}}$ \\
\hline Spirulina O & $6.62 \pm 1.30^{\mathrm{a}, \mathrm{b}}$ & $8.60 \pm 1.72^{\mathrm{a}}$ & $7.64 \pm 1.24^{\mathrm{a}, \mathrm{c}}$ & $3.26 \pm 0.15^{\mathrm{a}, \mathrm{b}, \mathrm{c}}$ & $2.23 \pm 0.15$ & $1.99 \pm 0.34^{\mathrm{a}, \mathrm{b}}$ & $0.71 \pm 0.01^{\mathrm{b}, \mathrm{c}, \mathrm{d}}$ \\
\hline \multicolumn{8}{|c|}{ p-Hydroxybenzoic acid } \\
\hline Spirulina B & $0.16 \pm 0.01^{\mathrm{a}}$ & $0.12 \pm 0.06^{\mathrm{a}}$ & $0.11 \pm 0.05^{\mathrm{a}}$ & $0.09 \pm 0.01^{\mathrm{a}}$ & $0.09 \pm 0.01^{\mathrm{a}}$ & $0.11 \pm 0.04^{\mathrm{a}}$ & $0.03 \pm 0.01^{\mathrm{a}}$ \\
\hline Spirulina $P$ & $0.45 \pm 0.07^{\mathrm{a}, \mathrm{b}}$ & $0.22 \pm 0.03^{b}$ & $0.29 \pm 002^{a, b}$ & $0.09 \pm 0.01^{\mathrm{b}}$ & $0.12 \pm 0.03$ & $0.22 \pm 0.05^{\mathrm{a}, \mathrm{b}}$ & $0.05 \pm 0.01^{\mathrm{b}}$ \\
\hline Spirulina M & $0.11 \pm 0.01^{\mathrm{b}, \mathrm{c}}$ & $0.13 \pm 0.05^{\mathrm{c}}$ & $0.14 \pm 0.02^{\mathrm{b}}$ & $0.22 \pm 0.03^{a, b, c}$ & $0.11 \pm 0.03^{c}$ & $0.08 \pm 0.00^{\mathrm{a}, \mathrm{b}}$ & $0.09 \pm 0.01^{\mathrm{a}, \mathrm{b}, \mathrm{c}}$ \\
\hline Spirulina N & $0.09 \pm 0.01^{\mathrm{b}, \mathrm{d}}$ & $0.08 \pm 0.00^{\mathrm{b}, \mathrm{d}}$ & $0.18 \pm 0.06$ & $0.34 \pm 0.02^{\mathrm{a}, \mathrm{b}, \mathrm{c}, \mathrm{d}}$ & $0.20 \pm 0.19$ & $0.07 \pm 0.01^{\mathrm{b}}$ & $0.37 \pm 0.01^{a, b, c, d}$ \\
\hline Spirulina $\mathrm{O}$ & $0.30 \pm 0.04^{a, b, c, d}$ & $0.44 \pm 0.01^{\mathrm{a}, \mathrm{b}, \mathrm{c}, \mathrm{d}}$ & $0.25 \pm 0.06^{\mathrm{a}}$ & $0.08 \pm 0.01^{\mathrm{cd} d}$ & $0.10 \pm 0.05^{\mathrm{d}}$ & $0.09 \pm 0.01^{\mathrm{b}}$ & $0.05 \pm 0.01^{\mathrm{cdd}}$ \\
\hline \multicolumn{8}{|c|}{ Syringic acid } \\
\hline Spirulina B & $0.37 \pm 0.03^{\mathrm{a}}$ & $0.21 \pm 0.02^{\mathrm{a}}$ & $0.28 \pm 0.07^{\mathrm{a}}$ & $0.10 \pm 0.01^{\mathrm{a}}$ & $0.08 \pm 0.01^{\mathrm{a}}$ & $0.07 \pm 0.005^{\mathrm{a}}$ & $0.02 \pm 0.001^{\mathrm{a}}$ \\
\hline Spirulina $P$ & $0.40 \pm 0.02^{b}$ & $0.38 \pm 0.02^{\mathrm{a}, \mathrm{b}}$ & $0.29 \pm 0.05^{\mathrm{b}}$ & $0.07 \pm 0.02^{\mathrm{b}}$ & $0.17 \pm 0.01^{\mathrm{a}, \mathrm{b}}$ & $0.21 \pm 0.01^{\mathrm{a}, \mathrm{b}}$ & $0.03 \pm 0.00^{\mathrm{ab}}$ \\
\hline Spirulina M & $0.04 \pm 0.0^{a, b}$ & $0.21 \pm 0.06^{\mathrm{a}, \mathrm{b}, \mathrm{c}}$ & $0.45 \pm 0.06^{\mathrm{a}, \mathrm{b}, \mathrm{c}}$ & $0.29 \pm 0.001^{\mathrm{a}, \mathrm{b}, \mathrm{c}}$ & $0.14 \pm 0.01^{\mathrm{acc}}$ & $0.05 \pm 0.005^{\mathrm{b}, \mathrm{c}}$ & $0.05 \pm 0.01^{\mathrm{a}, \mathrm{b}, \mathrm{c}}$ \\
\hline Spirulina N & $0.02 \pm 0.00^{\mathrm{a}, \mathrm{b}}$ & $0.02 \pm 0.00^{\mathrm{a}, \mathrm{b}, \mathrm{c}}$ & $0.05 \pm 0.01^{\mathrm{a}, \mathrm{b}, \mathrm{c}}$ & $0.19 \pm 0.02^{\mathrm{a}, \mathrm{b}, \mathrm{c}, \mathrm{d}}$ & $0.09 \pm 0.01^{\text {b.c.d }}$ & $0.05 \pm 0.01^{\mathrm{b}, \mathrm{d}}$ & $0.07 \pm 0.01^{a, b, c, d}$ \\
\hline Spirulina $\mathrm{O}$ & $0.04 \pm 0.00^{\mathrm{a}, \mathrm{b}}$ & $0.05 \pm 0.0^{\mathrm{a}, \mathrm{b}, \mathrm{c}}$ & $0.05 \pm 0.01^{\mathrm{a}, \mathrm{b}, \mathrm{c}}$ & $0.31 \pm 0.01^{\mathrm{a}, \mathrm{b}, \mathrm{d}}$ & $0.15 \pm 0.03^{\mathrm{a}, \mathrm{d}}$ & $0.13 \pm 0.04^{\mathrm{a}, \mathrm{b}, \mathrm{c}, \mathrm{d}}$ & $0.01 \pm 0.00^{\mathrm{b}, \mathrm{c}, \mathrm{d}}$ \\
\hline \multicolumn{8}{|c|}{ Cinnamic acid } \\
\hline Spirulina B & $0.11 \pm 0.01^{\mathrm{a}}$ & $0.01 \pm 0.00^{\mathrm{a}}$ & $0.07 \pm 0.01^{\mathrm{a}}$ & $0.03 \pm 0.00^{\mathrm{a}}$ & $0.08 \pm 0.005^{\mathrm{a}}$ & $0.10 \pm 0.01^{\mathrm{a}}$ & $0.01 \pm 0.00^{\mathrm{a}}$ \\
\hline Spirulina P & $0.04 \pm 0.005^{\mathrm{a}, \mathrm{b}}$ & $0.07 \pm 0.00$ & $0.05 \pm 0.00^{\mathrm{b}}$ & $0.11 \pm 0.003^{\mathrm{a}, \mathrm{b}}$ & $0.06 \pm 0.01^{\mathrm{a}, \mathrm{b}}$ & $0.06 \pm 0.001^{\mathrm{a}, \mathrm{b}}$ & $0.01 \pm 0.00^{\mathrm{b}}$ \\
\hline Spirulina M & $0.07 \pm 0.003^{\mathrm{a}, \mathrm{b}, \mathrm{c}}$ & $0.04 \pm 0.001^{\mathrm{c}}$ & $0.11 \pm 0.02^{a, b, c}$ & $0.11 \pm 0.01^{\mathrm{a}, \mathrm{c}}$ & $0.07 \pm 0.005^{\mathrm{c}}$ & $0.07 \pm 0.00^{\mathrm{a}, \mathrm{c}}$ & $0.04 \pm 0.002^{a, b, c}$ \\
\hline Spirulina N & $0.09 \pm 0.002^{\mathrm{a}, \mathrm{b}, \mathrm{c}}$ & $0.12 \pm 0.005^{\mathrm{a}, \mathrm{c}}$ & $0.07 \pm 0.00^{\mathrm{c}, \mathrm{d}}$ & $0.01 \pm 0.00^{\mathrm{a}, \mathrm{b}, \mathrm{c}, \mathrm{d}}$ & $0.01 \pm 0.00^{\mathrm{a}, \mathrm{b}, \mathrm{c}, \mathrm{d}}$ & $0.05 \pm 0.001^{\mathrm{a}, \mathrm{a}, \mathrm{d}}$ & $0.08 \pm 0.005^{\mathrm{a}, \mathrm{b}, \mathrm{c}, \mathrm{d}}$ \\
\hline Spirulina $\mathrm{O}$ & $0.04 \pm 0.005^{\mathrm{a}, \mathrm{c}, \mathrm{d}}$ & $0.12 \pm 0.06^{\mathrm{ac} c}$ & $0.03 \pm 0.003^{\mathrm{accd}}$ & $0.04 \pm 0.005^{\mathrm{b}, c, \mathrm{~d}}$ & $0.05 \pm 0.005^{\mathrm{a}, \mathrm{c}, \mathrm{d}}$ & $0.07 \pm 0.00^{\mathrm{a}, \mathrm{d}}$ & $0.02 \pm 0.00^{\mathrm{a}, \mathrm{b}, \mathrm{c}, \mathrm{d}}$ \\
\hline
\end{tabular}


Table 4. Continued.

\begin{tabular}{|c|c|c|c|c|c|c|c|}
\hline Artificial juice & \multicolumn{3}{|c|}{$\begin{array}{l}\text { Artificial stomach juice } \\
\text { (mg/100 g of preparation) }\end{array}$} & \multicolumn{3}{|c|}{$\begin{array}{l}\text { Artificial intestinal juice } \\
\text { (mg/100 g of preparation) }\end{array}$} & \\
\hline \multirow{2}{*}{ Preparation } & 15 & 30 & 60 & 150 & 150 & 150 & \\
\hline & \multicolumn{3}{|c|}{ (after 1 min incubation in artificial saliva) } & \multicolumn{3}{|c|}{ (after incubation in artificial stomach juice) } & \\
\hline $\begin{array}{c}\text { Extract to artificial } \\
\text { digestive juice }\end{array}$ & & & & & & & $\begin{array}{c}\text { Methanolic } \\
\text { extract (control) }\end{array}$ \\
\hline \multicolumn{8}{|c|}{ Quercetin } \\
\hline Spirulina B & $0.06 \pm 0.01^{\mathrm{a}}$ & $0.03 \pm 0.00^{\mathrm{a}}$ & $0.04 \pm 0.00^{\mathrm{a}}$ & $0.01 \pm 0.00^{\mathrm{a}}$ & $0.02 \pm 0.00^{\mathrm{a}}$ & $0.01 \pm 0.00^{\mathrm{a}}$ & $0.01 \pm 0.00^{\mathrm{a}}$ \\
\hline Spirulina P & $0.04 \pm 0.01^{1, \mathrm{~b}}$ & $0.21 \pm 0.02^{2, \mathrm{~b}}$ & $0.11 \pm 0.04^{4, \mathrm{~b}}$ & $0.01 \pm 0.00^{b}$ & $0.03 \pm 0.005^{a, b}$ & $0.18 \pm 0.001^{a, b}$ & $0.03 \pm 0.00^{a, b}$ \\
\hline Spirulina M & $0.02 \pm 0.00^{\mathrm{a}, \mathrm{b}}$ & $0.03 \pm 0.002^{\mathrm{b}}$ & $0.11 \pm 0.02^{a, c}$ & $0.02 \pm 0.002^{\mathrm{b}, \mathrm{c}}$ & $0.01 \pm 0.00^{\mathrm{a}, \mathrm{b}}$ & $0.01 \pm 0.00^{\mathrm{b}}$ & $0.03 \pm 0.02^{a, c}$ \\
\hline Spirulina N & $0.01 \pm 0.00^{\mathrm{a}, \mathrm{b}}$ & $0.01 \pm 0.00^{\mathrm{b}}$ & $0.01 \pm 0.00^{\mathrm{b}, \mathrm{c}}$ & $0.01 \pm 0.00^{c}$ & $0.01 \pm 0.00^{\mathrm{a}, \mathrm{b}}$ & $0.01 \pm 0.00^{\mathrm{b}}$ & $0.11 \pm 0.00^{\mathrm{abc,cd}}$ \\
\hline Spirulina $\mathrm{O}$ & $0.01 \pm 0.00^{\mathrm{a}, \mathrm{b}}$ & $0.01 \pm 0.00^{b}$ & $0.02 \pm 0.00^{b, c}$ & $0.01 \pm 0.000^{c}$ & $0.01 \pm 0.00^{\mathrm{a}, \mathrm{b}}$ & $0.01 \pm 0.00^{\mathrm{b}}$ & $0.02 \pm 0.00^{\mathrm{ab}, \mathrm{bc} . \mathrm{d}}$ \\
\hline
\end{tabular}

Data are presented as the mean \pm standard deviation $(\mathrm{SD}) ; \mathrm{n}=6$ repetitions Tukey-Kramer test was used to reveal the differences between paired groups of phenolic compounds in rows, the same letters (a, b, c, d) are marked for the content whose differences are statistically significant (for $\mathrm{p}$ values < 0.05) (GraphPad InStat)

highest for capsules (up to $6.8 \mathrm{mg} /$ day) and the lowest for lyophilizate (up to $2.6 \mathrm{mg} / \mathrm{day}$ ).

In summary, the release of zinc and organic compounds from preparations containing A. platensis depended on the time of incubation and the degree of degradation in artificial digestive juices. Artificial digestive juices did not break down $A$. platensis-containing tablets even after a maximum incubation period of $60 \mathrm{~min}$ in artificial stomach juice and $150 \mathrm{~min}$ in artificial intestinal juice. During extractions was observed the formation of a gelatinous layer on the surface to prevent liquid penetration into the interior and further disintegration of the tablet mass. After the tablet was cut into two parts, the completely dry core was clearly visible inside.

Thereby, was decided to study the physical properties of tablets containing A. platensis according to European Pharmacopeia $8^{\text {th }}$ ed (25). The physical properties of prepared tablets are shown in Table 6.

The controlled tablets were elegant in appearance. The thickness of the tablets ranged from 4.74 to $4.99 \mathrm{~mm}$. For formulation Spirulina O percent deviations of thickness exceeded 5\% (acceptable range of thickness is $\pm 5 \%$ ). Average weight, hardness, and friability were within pharmacopeia specification. The variation in weight ranged from 255.3 to $401.5 \mathrm{mg}$ (acceptable range of weight variation is $\pm 5 \%$ ). The hardness of tablets ranged from 62.4 to $64.3 \mathrm{~N}$ (acceptable range of hardness is $>40$ $\mathrm{N}$ ) and friability ranged from 0.15 to $0.22 \%$ (acceptable range of friability is $<1 \%$ ). The disintegration times of investigated tablets exceed $15 \mathrm{~min}$. Tablet formulations had excessively long disintegration times which amounted from 72.3 to $81.2 \mathrm{~min}$. The average disintegration time of investigated tablets was found to be up to $76.7 \mathrm{~min}$. According to European Pharmacopeia $8^{\text {th }}$ ed., the disintegration times for these preparations should be less than 15 min. Hence, on the basis of the conducted studies, was found that A. platensis in the form of tablets cannot be a good source of zinc and organic compounds in the human diet. Of the three preparations containing A. platensis tested in accordance with the pharmacopeia regulations, only capsule form complied with the pharmacopeia standards. The deviations of weight in capsule ranged from 0.2 to $3.6 \%$ and the disintegration time was found to be 11.5 $\min$.

\section{Chemometric analysis}

Chemometric tools were used to obtain deeper information of the obtained dataset (results of indole and phenolic compounds performed for preparations containing A. platensis). The analysis was based on Table 4. and 5. The objects of analysis were preparations containing A. platensis in various forms (powder, tablets, and capsules), described by parameters - analyzed indole and phenolic compounds. Chemometric analysis for such a dataset, characterized by a wide range of variability, allowed the extraction of additional information on the correlations that occur between the analyzed objects preparations containing A. platensis. Two methods for chemometric analysis were used in the study: cluster analysis (CA) and principal component analysis (PCA). CA method indicated the similarity 
Table 5. The content of indole compounds released to artificial digestive juices from selected Arthrospira platensis - containing preparations.

\begin{tabular}{|c|c|c|c|c|c|c|c|}
\hline Artificial juice & \multicolumn{3}{|c|}{$\begin{array}{l}\text { Artificial stomach juice } \\
\text { (mg/100 g of preparation) }\end{array}$} & \multicolumn{3}{|c|}{$\begin{array}{l}\text { Artificial intestinal juice } \\
\text { (mg/100 g of preparation) }\end{array}$} & \multirow{3}{*}{ Control } \\
\hline Time $[\mathrm{min}]$ & 15 & 30 & 60 & 150 & 150 & 150 & \\
\hline Preparation & \multicolumn{3}{|c|}{ (after 1 min incubation in artificial saliva) } & \multicolumn{3}{|c|}{ (after incubation in artificial stomach juice) } & \\
\hline \multicolumn{8}{|c|}{ 5-Hydroxy-L-tryptophan } \\
\hline Extract & & & & & & & Control \\
\hline Spirulina B & $124.14 \pm 10.3^{a}$ & $18.10 \pm 0.81^{\mathrm{a}}$ & $88.73 \pm 12.0^{\mathrm{a}}$ & $45.74 \pm 1.79^{\mathrm{a}}$ & $35.56 \pm 4.21^{\mathrm{a}}$ & $50.02 \pm 8.78^{a}$ & $11.47 \pm 0.71^{\mathrm{a}}$ \\
\hline Spirulina $P$ & $117.35 \pm 2.41^{\mathrm{a}, \mathrm{b}}$ & - & $25.02 \pm 1.21^{\mathrm{a}, \mathrm{b}}$ & $33.81 \pm 5.67^{\mathrm{b}}$ & $29.07 \pm 4.31^{\mathrm{b}}$ & $21.25 \pm 1.41^{\mathrm{a}, \mathrm{b}}$ & $9.54 \pm 0.15^{\mathrm{b}}$ \\
\hline Spirulina M & $27.17 \pm 2.98^{\mathrm{a}, \mathrm{b}}$ & $80.28 \pm 1.60^{\mathrm{a}, \mathrm{b}, \mathrm{c}}$ & - & $156.20 \pm 17.2^{\mathrm{a}, \mathrm{b}}$ & $96.69 \pm 11.06^{\mathrm{a}, \mathrm{b}}$ & $28.70 \pm 1.71^{\mathrm{a}}$ & - \\
\hline Spirulina N & $22.07 \pm 1.93^{\mathrm{a}, \mathrm{b}}$ & $3.47 \pm 0.04^{\mathrm{a}, \mathrm{b}, \mathrm{c}}$ & $46.46 \pm 3.96^{\mathrm{a}, \mathrm{b}, \mathrm{c}, \mathrm{d}}$ & $33.02 \pm 3.97^{c}$ & $60.51 \pm 5.84^{\mathrm{a}, \mathrm{b}, \mathrm{d}}$ & $23.39 \pm 1.18^{a}$ & $29.49 \pm 1.61^{a, b, c}$ \\
\hline Spirulina O & $27.19 \pm 1.02^{\mathrm{a}, \mathrm{b}}$ & $42.23 \pm 3.62^{a, b, d}$ & $27.71 \pm 2.43^{\mathrm{a}, \mathrm{c}, \mathrm{d}}$ & $42.03 \pm 2.24^{c}$ & $34.56 \pm 3.43^{\mathrm{cdd}}$ & $33.29 \pm 2.92^{\mathrm{a}, \mathrm{b}}$ & - \\
\hline \multicolumn{8}{|c|}{ Tryptamine } \\
\hline Extract & & & & & & & Control \\
\hline Spirulina B & - & - & - & $1.54 \pm 0.00^{\mathrm{a}}$ & $1.57 \pm 0.01^{\mathrm{a}}$ & $5.37 \pm 0.80^{\mathrm{a}}$ & - \\
\hline Spirulina $P$ & $1.66 \pm 0.01$ & - & - & $1.57 \pm 0.00^{b}$ & $1.83 \pm 0.03^{\mathrm{b}}$ & $1.71 \pm 0.20^{\mathrm{a}, \mathrm{b}}$ & - \\
\hline Spirulina M & - & $2.37 \pm 0.00$ & - & $3.66 \pm 0.38^{\mathrm{a}, \mathrm{b}, \mathrm{c}}$ & $2.94 \pm 0.38^{\mathrm{a}, \mathrm{b}, \mathrm{c}}$ & $4.23 \pm 0.17^{\mathrm{ab}, \mathrm{c} c}$ & - \\
\hline Spirulina N & - & $1.68 \pm 0.15$ & $1.36 \pm 0.01$ & - & - & - & - \\
\hline Spirulina O & - & - & - & $3.18 \pm 0.08^{a, b, c, d}$ & $2.37 \pm 0.37^{\mathrm{a}, \mathrm{d}}$ & $2.49 \pm 0.09^{\mathrm{a}, \mathrm{c}, \mathrm{d}}$ & - \\
\hline \multicolumn{8}{|c|}{ 5-Methyltryptamine } \\
\hline Extract & & & & & & & Control \\
\hline Spirulina B & - & - & $3.27 \pm 0.00$ & $3.43 \pm 0.01$ & $3.21 \pm 0.01$ & $3.21 \pm 0.01$ & $0.69 \pm 0.01$ \\
\hline Spirulina P & - & - & - & - & - & - & - \\
\hline Spirulina M & - & - & - & - & - & - & - \\
\hline Spirulina N & - & - & - & - & - & - & - \\
\hline Spirulina $\mathrm{O}$ & - & - & - & - & - & - & - \\
\hline \multicolumn{8}{|c|}{ 6-Methyl-L-tryptophan } \\
\hline Extract & & & & & & & Control \\
\hline Spirulina B & $1.57 \pm 0.08^{\mathrm{a}}$ & $1.03 \pm 0.00^{\mathrm{a}}$ & $1.40 \pm 0.10^{\mathrm{a}}$ & $1.12 \pm 0.01^{\mathrm{a}}$ & $0.92 \pm 0.08^{a}$ & - & - \\
\hline Spirulina P & $3.71 \pm 0.18^{\mathrm{a}, \mathrm{b}}$ & $3.92 \pm 0.21^{\mathrm{a}, \mathrm{b}}$ & $1.41 \pm 0.22^{\mathrm{b}}$ & $1.92 \pm 0.33^{\mathrm{a}, \mathrm{b}}$ & $2.94 \pm 0.11^{\mathrm{a}, \mathrm{b}}$ & $5.00 \pm 0.26^{\mathrm{a}, \mathrm{b}}$ & $0.76 \pm 0.04^{b}$ \\
\hline Spirulina M & $3.06 \pm 0.21^{\mathrm{a}, \mathrm{b}, \mathrm{c}}$ & $10.23 \pm 1.74^{\mathrm{a}, \mathrm{b}, \mathrm{c}}$ & $4.91 \pm 0.08^{\mathrm{a}, \mathrm{b}}$ & - & - & $1.04 \pm 0.01^{\mathrm{a}, \mathrm{b}, \mathrm{c}}$ & - \\
\hline Spirulina N & $2.44 \pm 0.11^{a, b, c, d}$ & - & - & $0.26 \pm 0.01^{\mathrm{a}, \mathrm{b}}$ & $0.74 \pm 0.09^{b, c, d}$ & - & $1.38 \pm 0.01^{\mathrm{b}}$ \\
\hline Spirulina O & $1.00 \pm 0.08^{a, b, c, d}$ & $1.88 \pm 0.83^{\mathrm{c}}$ & $1.13 \pm 0.20^{\mathrm{c}, \mathrm{d}}$ & - & $0.74 \pm 0.04^{\mathrm{a}, \mathrm{b}, \mathrm{d}}$ & $0.58 \pm 0.04^{\mathrm{a}, \mathrm{b}, \mathrm{cd}}$ & - \\
\hline \multicolumn{8}{|c|}{ L-Tryptophan } \\
\hline Extract & & & & & & & Control \\
\hline Spirulina B & $2.39 \pm 0.78^{a}$ & $27.7 \pm 0.32^{\mathrm{a}}$ & $1.69 \pm 0.42^{\mathrm{a}}$ & $1.50 \pm 0.10$ & $0.50 \pm 0.01$ & - & - \\
\hline Spirulina P & $2.61 \pm 0.25^{\mathrm{b}}$ & $12.03 \pm 0.46^{\mathrm{a}, \mathrm{b}}$ & $0.46 \pm 0.00^{\mathrm{a}, \mathrm{b}}$ & - & - & - & - \\
\hline Spirulina M & $9.60 \pm 0.78^{a, b, c}$ & $18.45 \pm 1.75^{\mathrm{a}, \mathrm{b}, \mathrm{c}}$ & $1.26 \pm 0.05^{\mathrm{a}, \mathrm{b}, \mathrm{c}}$ & $2.92 \pm 0.00$ & $1.08 \pm 0.10$ & - & - \\
\hline Spirulina N & $0.76 \pm 0.06^{\mathrm{a}, \mathrm{b}, \mathrm{c}}$ & - & $0.83 \pm 0.04^{\mathrm{a}, \mathrm{b}, \mathrm{c}}$ & - & - & - & - \\
\hline Spirulina O & - & $1.09 \pm 0.40^{\mathrm{b}, \mathrm{c}}$ & $0.75 \pm 0.03^{a, b, c}$ & - & - & - & - \\
\hline
\end{tabular}

Data are presented as the mean \pm standard deviation (SD); $\mathrm{n}=6$ repetitions Tukey-Kramer test was used to reveal the differences between paired groups of phenolic compounds in rows, the same letters (a, b, c, d) are marked for the content whose differences are statistically significant (for $\mathrm{p}$ values < 0.05) (GraphPad InStat) 
between the examined objects (preparations containing $A$. platensis). In case of this analysis, the similarity of objects is demonstrated by their close relative position in multidimensional space. The graphical image of the CA analysis is the dendrogram (Fig. 2), in which the objects characterized by considerable similarity form the clusters. In this instance, the $x$ and $y$-axes do not correspond to the Cartesian numerical axes $(31,32)$. The analyzed objects (A. platensis preparations) were marked on the $x$-axis, whereas the distance between the examined objects calculated on the basis of Ward's agglomeration method on the $y$-axis. Three major clusters were observed based on the similarity analysis (CA - Fig. 2). The first cluster formed preparations in the form of capsules, while the remaining clusters were formed from preparations in the form of tablets or powders. Their membership in particular clusters indicates their similarity within particular clusters. This similarity may be related to the composition of the examined preparations (content of indole and phenolic compounds) as well as the degree of release of the examined metabolites into the digestive juices.

Short dendrogram arms in case of preparations in the form of tablets show the highest correlation similarity within these preparations $(31,33)$. In addition, the differences between the preparations (capsules and tablets and powdered form) belonging to other clusters may result from unequal conditions of A. platensis culture and depend on the type of $A$. platensis used in the preparations; therefore, there are discrepancies for metabolites released into the digestive juices.

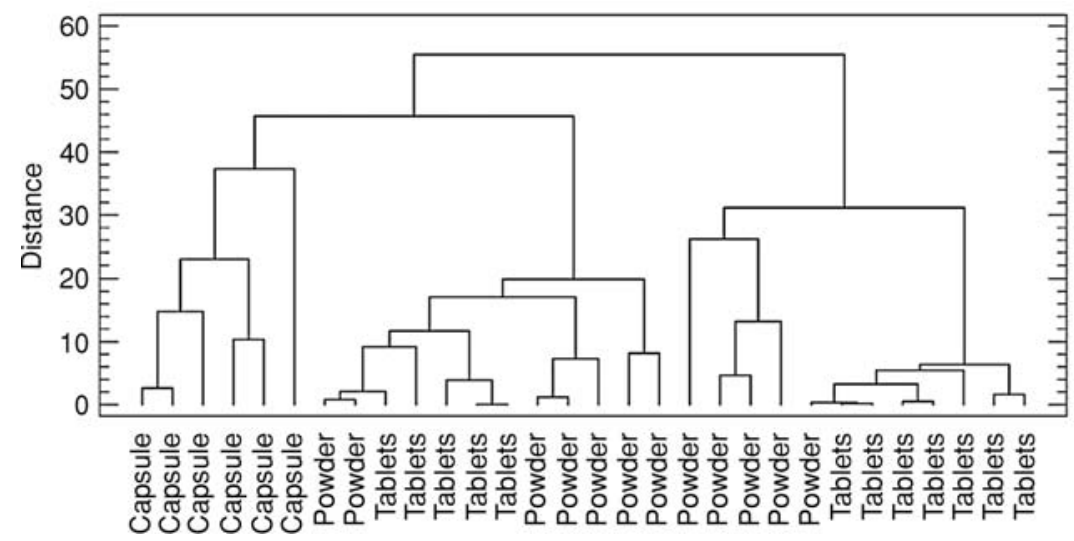

Figure 2. Dendrogram presenting similarity between the objects (preparations containing Arthrospira platensis) depending on the form of preparation (City-Block, Ward's algorithm). The analysis was performed in Statgraphics Centurion XVII program

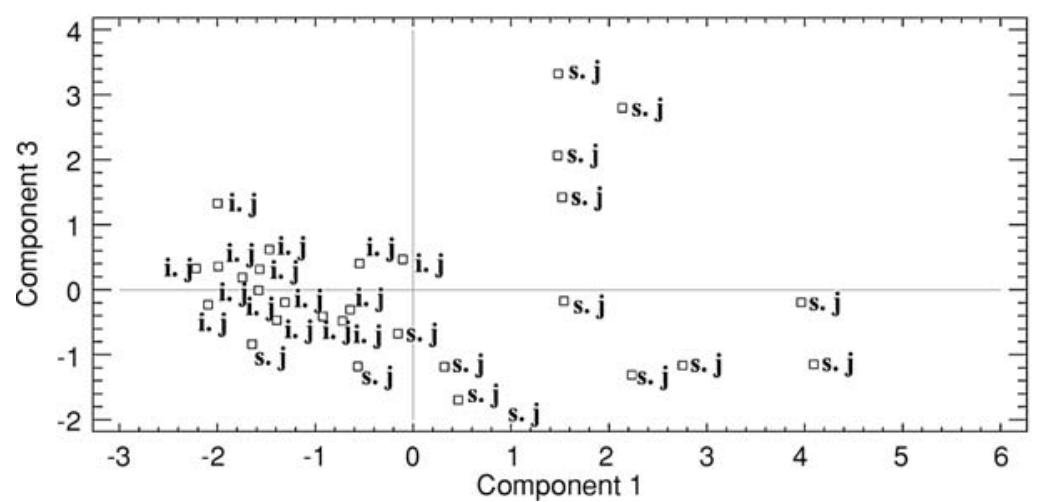

Figure 3. Scatterplot - similarity of the analyzed preparation with Arthrospira platensis with respect to the site of release phenolic and indole compounds (s. j-stomach juice, i. j-intestinal juice). The analysis was performed in Statgraphics Centurion XVII program 


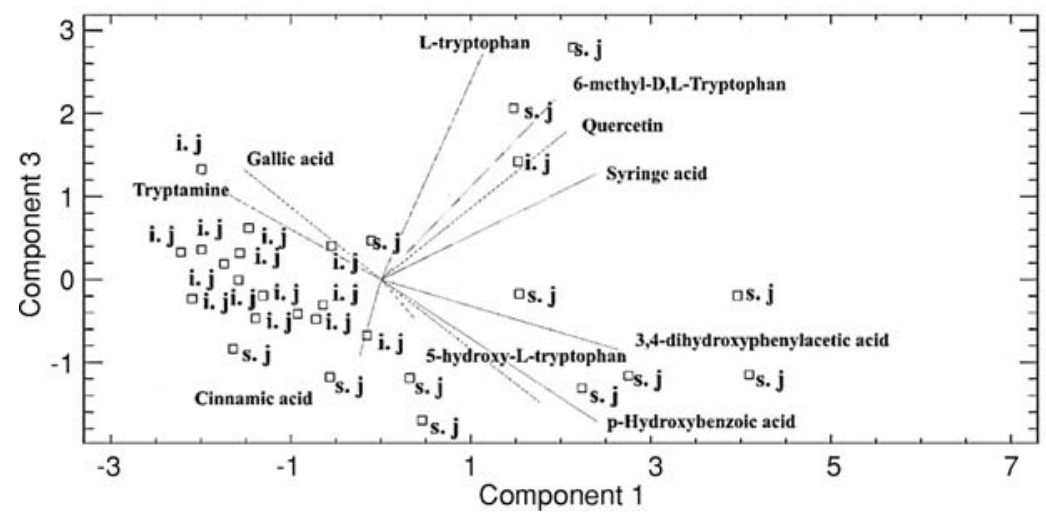

Figure 4. Biplot diagram presenting the correlation between the analyzed organic compound present in the preparations containing Arthrospira platensis and the site of their release in human digestive tract (s. j-stomach juice, i. j-intestinal juice). The analysis was performed in Statgraphics Centurion XVII program

Table 6. Evaluation of physical properties of prepared tablets (mean \pm standard deviation).

\begin{tabular}{|c|c|c|c|c|c|}
\hline Formulation & $\begin{array}{c}\text { Weight variation } \\
(\mathrm{mg})\end{array}$ & $\begin{array}{c}\text { Thickness } \\
(\mathrm{mm})\end{array}$ & $\begin{array}{c}\text { Friability } \\
(\%)\end{array}$ & $\begin{array}{c}\text { Breaking force } \\
(\mathrm{N})\end{array}$ & $\begin{array}{c}\text { Disintegration time } \\
(\mathrm{min})\end{array}$ \\
\hline Spirulina M & $443.0 \pm 4.62$ & $7.5 \pm 1.10$ & - & - & $11.5 \pm 1.05$ \\
\hline Spirulina N & $401.45 \pm 4.21$ & $4.74 \pm 0.03$ & 0.219 & $62.4 \pm 7.06$ & $81.17 \pm 5.56$ \\
\hline Spirulina O & $255.3 \pm 5.09$ & $4.99 \pm 0.12$ & 0.15 & $64.3 \pm 6.38$ & $72.33 \pm 4.59$ \\
\hline
\end{tabular}

Table 7. Factor loads for three first main principal components (PC1, PC2, and PC3).

\begin{tabular}{|l|c|c|c|}
\hline \multicolumn{1}{|c|}{ Compounds } & PC1 & PC2 & PC3 \\
\hline 3,4-Dihydroxyphenylacetic acid & 0.450 & 0.217 & -0.170 \\
\hline 5-Hydroxy-L-tryptophan & 0.061 & 0.581 & -0.090 \\
\hline 6-methyl-D,L-Tryptophan & 0.314 & -0.070 & 0.415 \\
\hline Cinnamic acid & -0.038 & 0.226 & -0.173 \\
\hline Gallic acid & -0.242 & 0.495 & 0.249 \\
\hline L-Tryptophan & 0.186 & -0.137 & 0.528 \\
\hline p-Hydroxybenzoic acid & 0.279 & 0.047 & -0.277 \\
\hline Protocatechuic acid & 0.422 & 0.084 & -0.355 \\
\hline Quercetin & 0.326 & -0.061 & 0.333 \\
\hline Syringic acid & 0.381 & 0.352 & 0.240 \\
\hline Tryptamine & -0.303 & 0.397 & 0.216 \\
\hline
\end{tabular}

The second method complementary to the CA used in this study is PCA. PCA allows the reduction of the measurement data space to the minimum necessary to characterize the interactions between them. A large number of parameters (measured content of indole and phenolic compounds) describing ana- lyzed objects (preparations with A. platensis) made the direct visualization of multidimensional data space complicated. In order to facilitate it, the number of data was reduced by correlating them. Output parameters were replaced by new variables - primary components. PCA analysis demonstrated that 
$61.92 \%$ of the variations in the examined data set can be described by the three primary components (PC1, $\mathrm{PC} 2$, and PC3). Consequently, the remaining components were not considered for further analysis. The three primary components (PC1, PC2, and PC3) are a linear combination of primary variables multiplied by corresponding charges. The values of the charges that correspond to the correlation coefficient with the primary variables are summarized in Table 7 . For the PC1 component, its magnitude is considerably affected by the measured value ofthe phenolic compound, that is, 3,4-dihydroxyphenylacetic acid. The other main components, $\mathrm{PC} 2$ and $\mathrm{PC} 3$, can be interpreted in the same way. Consequently, the reduction of the input data area to the three primary components allowed for analysis in two-dimensional space (Fig. 3) $(34,35)$. Two distinct clusters were distinguished analyzing the examined objects (preparations with $A$. platensis) in relation to the site in the digestive system, where phenolic and indole compounds were released (Fig. 3). These compounds are to a various degree released into an artificial stomach and intestinal juices, as evidenced by their belonging to distinct groups. Such division indicates that the examined organic components are released into the digestive juices to varying degrees, which in turn, depends on the release site in the condition imitated human digestive tract. In addition, considering the Biplot diagram (Fig. 4) based on the two primary components (PC1 and PC3), the preference of components to the site where they were released into the artificial digestive tract was analyzed. On this basis, was found that the release of indole and phenolic compounds from preparations containing A. platensis into artificial digestive juices depended on the type of artificial digestive juice. The organic compounds from the preparations were to the highest degree released into stomach juices, which confirms the direction of the arms in the Biplot diagram (Fig. 4). Only sparse phenolic compounds (gallic acid and cinnamic acid) and indole ones (tryptamine) were released from the preparations mostly to intestinal juice.

\section{CONCLUSIONS}

The experiment presented that the active substances in the commercial preparations are not completely released into the artificial digestive juices and hence may not be potentially available to human. The quantities of released zinc (II) ions from preparations containing A. platensis are insufficient for human body according to the daily requirement for this element. In the case of phenolic compounds, their amounts were found to be higher in the extracts of artificial digestive juices than that of methanolic extracts of the tested preparations. In this way, it has been adequately shown that the content of active substance in medicinal preparations is not the same as its amount released into digestive juices which suggest the need for such analyzes. The experiment further showed that only hard capsules met the European Pharmacopeia $8^{\text {th }}$ ed standards whereas tablets did not. Due to this fact, an important element of research on dietary supplements is the evaluation of their formulations' quality and the definition of a form that allows the release of biologically active compounds in the most effective manner.

\section{Acknowledgments}

This project was partially supported by Jagiellonian University Medical College project: K/ZDS/005619.

\section{REFERENCES}

1. Abdulqader G., Barsanti L., Tredici M.: J. Appl. Phycol. 12, 493 (2000).

2. Belay A.: JANA 5, 27 (2002).

3. Ramakrishnan R.: Int. J. Curr. Med. Pharm. 3, 159 (2013).

4. Ronda S.R., Bokka C.S., Ketineni C., Rijal B., Alu P.R.: Braz. J. Microbiol. 43, 12 (2012).

5. Qiang H., Zhengyu H., Cohen Z., Richmond A.: Eur. J. Phycol. 32, 81 (1997).

6. Kulshreshtha A., Jarouliya U., Bhadauriya P., Prasad G., Bisen P.: Curr. Pharm. Biotechnol. 9, 400 (2008).

7. Kumar V., Bhatnagar A., Srivastava J.: J. Med. Plants 5, 7043 (2011).

8. Qiang H., Zarmi Y., Richmond A.: Eur. J. Phycol. 33, 165 (1998).

9. Deng R., Chow T.: Cardiovasc. Ther. 28, 33 (2010).

10. Hwang J., Lee I., Jeng K., Wang M., Hou R. et al.: J. Nutr. Sci. Vitaminol. 57, 186 (2011).

11. Sabina E., Samuel J., Rajappa R., Patel S., Mandal N. et al.: IJIB 6, 1 (2009).

12. Yang L., Wang Y., Zhou Q., Chen P., Wang Y. et al.: Mol. Vis. 15, 1951 (2009).

13. Bolanho B., Egea M., Jácome A., Campos I., Monteiro de Carvalho J., Danesi E.: Food. Nutr. Res. 53, 171 (2014).

14. Bhowmik D., Dubey J., Mehra S.: World J. Dairy Food Sci. 4, 160 (2009).

15. Rasool M., Sabina E., Lavanya B.: Biol. Pharm. Bull. 29, 2483 (2006). 
16. Yang L., Zhou Q.J., Wang Y., Gao Y., Wang Y.Q.: Int. J. Ophthalmol. 5, 32 (2012).

17. Tapiero H., Tew K.D.: Biomed. Pharmacother. 57, 399 (2003).

18. Hambidge K.M., Krebs N.F.: J. Nutr. 137, 1101 (2007).

19. Misbahuddin M., Maidul Islam A.Z.M., Khandker S., Ifthaker-Al-Mahmud N.: Clin. Toxicol. 44, 135 (2006).

20. Rojowski J., Zając M., Muszyńska B., Opoka W.: Acta. Pol. Pharm. 74, 597 (2017).

21. PTFarm. Polish Pharmakopeia, Wydanie X, Warszawa 2014.

22. Neumann M., Goderska K., Grajek K., Grajek W.: ŻNTJ 1, 30 (2006).

23. Opoka W., Muszyńska B., Rojowski J., Rumian J.: Gastroel-2014. Poland Patent Application P 417238 (2016).

24. Sułkowska-Ziaja K., Maślanka A., Szewczyk A., Muszyńska B.: Nat. Prod. Commun. 12, 363 (2017).

25. Council of Europe. European Pharmacopeia $8^{\text {th }}$ ed., Strasbourg 2013.
26. Karkos P.D., Leong S.C., Karkos C.D., Sivaji N., Assimakopoulos D.A.: Evid. Based Complement. Alternat. Med. 2, 1 (2011).

27. Al-Dhabi N.A.: Saudi. J. Biol. Sci. 20, 383 (2013).

28. Hunt J.R.: Am. J. Clin. Nutr. 78, 633 (2003).

29. Manach C., Scalbert A., Morand C., Rémésy C., Jiménez L.: Am. J. Clin. Nutr. 79, 727 (2004).

30. Balasundram N., Sundram K., Samman S.: Food Chem. 99, 191 (2006).

31. Gemperline P.: Practical guide to chemometrics. Taylor \& Francis, London 2006.

32. Miller J.N., Miller J.C.: Statistics and chemometrics for analytical chemistry. Prentice Hall, London 1999.

33. Johnson R.: Elementary Statistics $4^{\text {th }}$ Edition, PWN Publishers, USA 1984.

34. Malinowski E.R.: Factor analysis in chemistry. John Wiley \& Sons, New York 1991.

35. Massart D.L., Vander H.Y.: LC GC Eur. 18, 84 (2004).

Received: 12.11.2017 